\title{
マウス移植悪性腫瘍に対するイミタンソール化合物の 放射線増感作用について
}

第 3 報：エールリッヒ癌に対する 5-methoxy carbonyl-2-methyl sulfinyl-1-methylimidazole の放射線增感作用—

酒泉和夫・瀬沼 滋・佐藤一人・永井哲夫* 藤 野雅美*・高門 渡*

\section{Experimental radiosensitizer therapy for malignant} tumor transplanted into mice - (3) Radiosensitive effect of 5-methoxy carbonyl-2- methyl sulfinyl-1-methylimidazole for Ehrlich solid carcinoma-

\author{
Kazuo Sakaizumi - Shigeru Senuma - Kazuhito Sato \\ Tetsuo NAgai* • Masami Fujino* - Wataru TAKakado*
}

\begin{abstract}
We have already reported that the effectiveness of radiosensitization and nitro-group radiosensitizer misonidazole (MISO) and dinitroimidazole-ethanol (DNIE).

These radiosensitizers have some side effects on human and mice.

5-methoxy carbonyl-2-methyl sulfinyl-1-methyl imidazole (KIH-3) is a non nitro-group radiosensitizers of hypoxic tumor cells.

Then, the purpose of our studies to compare the sensitizers emhancement of MISO, DNIE and $\mathrm{KIH}-3$.

On in vitro, $\mathrm{KIH}-3$ had effected 5 times of MISO in V 79 cell culture, so we have examined to give 100/mouse but all mice died (nude 5, ddY 5, conv. 5).

The safe maximum dosage of $\mathrm{KIH}-3$ was $40 \mathrm{mg} / \mathrm{mouse}$.

Methods and evaluation: Battelle Columbus Laboratories Protocol.

Radiation: ${ }^{60} \mathrm{Co} 15 \mathrm{~Gy}$ local radiation. These radiosensitizers were administrated into the mice's abdomen prior to 30 minutes of local irradiation.

Tumor: Ehrlich solid carcinoma. On the first day of the experiment, $2 \sim 3$ pieces of a $1 \sim$ $3 \mathrm{~mm}$ tumor block in Eagle's MEM medium were transplanted to subcutaneous of the right thight of each mouse.

Animals: Male nude ICR mice, ddY mice and conventionl ICR mice (10 weeks, $20 \sim 25 \mathrm{~g}$ ).

Results: On Ehrlich solid carcinoma of nude mice and conv. ICR mice, KIH-3+ ${ }^{60} \mathrm{Co} 15 \mathrm{~Gy}$ therapies were more effective than the control group, but the carcinoma increased on ddY mice.

There were no significant difference in the tumore growth of nude, ddY and conv. ICR mice between $\mathrm{KIH}-3$ combination therapy group and ${ }^{60} \mathrm{Co} 15 \mathrm{~Gy}$ single dose therapy group.
\end{abstract}

Key words: non-nitro radiosensitizer, Ehrlich solid carcinoma, experimental radiotherapy

東海大学医学部口腔外科学教室

（指道：酒泉和夫教授）

* 慶応義熟大学医学部菌科口腔外科学教室 （主任：野本種邦教授）

Department of Oral Surgery, School of Medicine, Tokai University (Group chairperson: Prof.
Kazuo Sakaizumi)

* Department of Dentistry and Oral Surgery, School of Medicine, Keio University (Chief: Prof. Tanekuni Nomoto) 受付日：昭和 60 年 10 月 22 日 
緒

言

5-methoxy carbonyl-2-sufinyl-1-methyl imidazole （KIH-3）は放射線増感作用を期待して分子設計された イミダゾール化合物で，図1飞示す分子式を有し無味・ 無臭の水湾よく溶解する白色粉末である。電子親和性は -1.41で misonidazole (MISO) の-1.40 に類似して いる1,2) 第 1，2 報で述べたように MISO および dinitroimidazole ethanol (DNIE)は $\mathrm{NO}_{2}$ 基をむつイミダ ゾール化合物で，DNIE はいまた臨床応用の時期にいた っていないが, MISO では悪心・嘔吐・難聴等の副作用 がみられ，その原因としてこの $\mathrm{NO}_{2}$ 基が推定された. 本 化合物は MISO - DNIE と類似する分子式であるが， $\mathrm{NO}_{2}$ 基を有せず低い毒性・低副作用が期待されている。 著者らは本剤をマウス移植エールリッヒ癌に使用し, Battelle Columbus Laboratories Protocol により実験治 療を行いその効果を判定した。

\section{実 験 方 法}

動 物：ddY マウス雄（日本クレア）, 通常 ICR マ

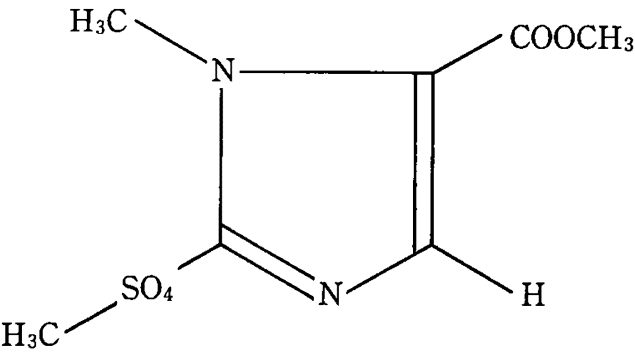

図 1 5-methoxy carbonyl-2-sufinyl-1-methylimidazole $=\mathrm{KIH}-3$
ウス雄（日本チャールズリバー）ヌード CD-1・ICR マ ウス雄（日本チャールズリバー）でいずれも 8 週踰体重 約 $20 \mathrm{~g}$ で，1 群 4 〜 5 匹として実験した，通常マウス は通常クリーン環境、ヌードマウスはビニールアイソレ 一タ内で飼育した。

腫 瘍：あらかじめ上記の 3 種類のマウスに継代移植 してあったエールリッヒ固型癌をクリーンベンチ内で可 及的に無菌的に摘出, MEM 培養液中で細切その $2 \sim 3$ 片をマウス右側大腿部皮下へトロカール針を用いて移植 した．実験開始時の腫演の大きさはプロトコールにより 短径 ${ }^{2} \times$ 長径 $/ 2$ の式で得れる $100 \sim 300 \mathrm{mg}$ の範囲内と した ${ }^{3)}$

薬刜投与 : KIH-3 はマウス 1 匹当たり $40 \mathrm{mg} / 1 \mathrm{~m} l$ と して腹腔内へ投与，30分後に放射線照射した。

放射線照射：マウス右大腿部が中央に集まるように動 物を放射状に系にて板上に固定, ${ }^{60} \mathrm{Co} \gamma$ 線 $15 \mathrm{~Gy}$ を局 所照射した。

\section{実 験 結 果}

図 2はヌード ICR マウス上のエールリッヒ癌に対す る $\mathrm{KIH}-340 \mathrm{mg}+{ }^{60} \mathrm{Co} 15 \mathrm{~Gy}$ 併用治療群とその他の治 療群の畽瘍增殖を画いたグラフで，実験開始時の腫湯の 大ささが相違するだめ治療効果以外の影響が表れて、ス タート時に腫瘍大なるるのは一見効果が低い印象経過と なり，また腫瘍小なるものは一見効果が高い上うにみ兄 るが，11日目では ${ }^{60} \mathrm{Co} 15 \mathrm{~Gy}$ 群・DNIE $10 \mathrm{mg}+{ }^{60} \mathrm{Co}$ $15 \mathrm{~Gy}$ 群・MISO $20 \mathrm{mg}+{ }^{60} \mathrm{Co} 15 \mathrm{~Gy}$ 群の 3 群が同時 にグラフ線の下降するのが観察され, 軽度ながら增殖抑 制を諗めた。図了は図 2 を補正したグラフで，実験開始 時の腫場を $100 \mathrm{mg}$ と仮定し，おの括のの治療効果の羑 を明らかにする目的で画いた。

図 3 では実験全期間を通して增殖著明なコントロール 群・ ${ }^{60} \mathrm{Co} 15 \mathrm{~Gy}$ 群・DNIE $2 \mathrm{mg}+{ }^{60} \mathrm{Co} 15 \mathrm{~Gy}$ 群の 3 群

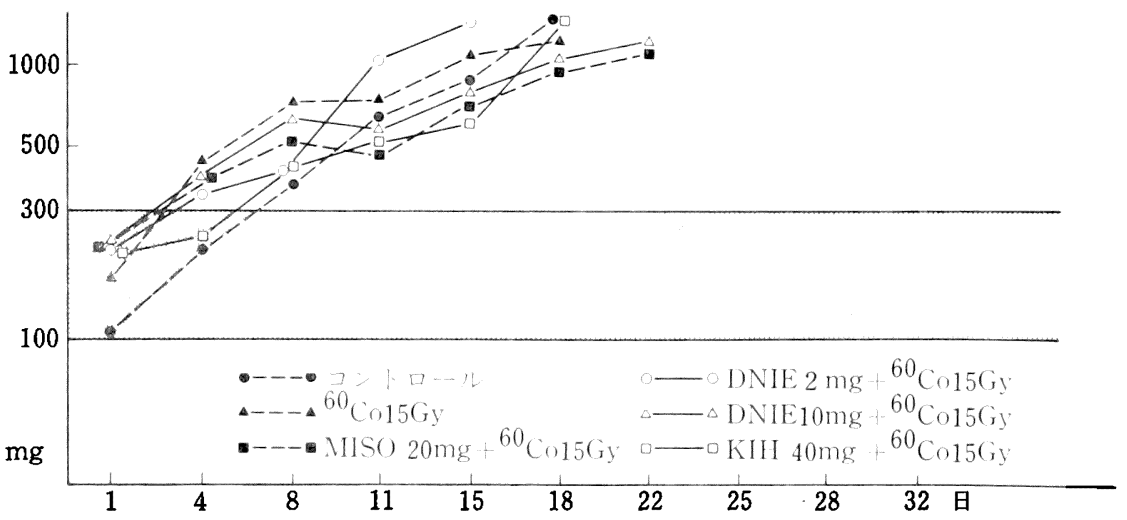

図 2 エールリッヒ瘦の增殖曲線（ヌードICR マウス） 


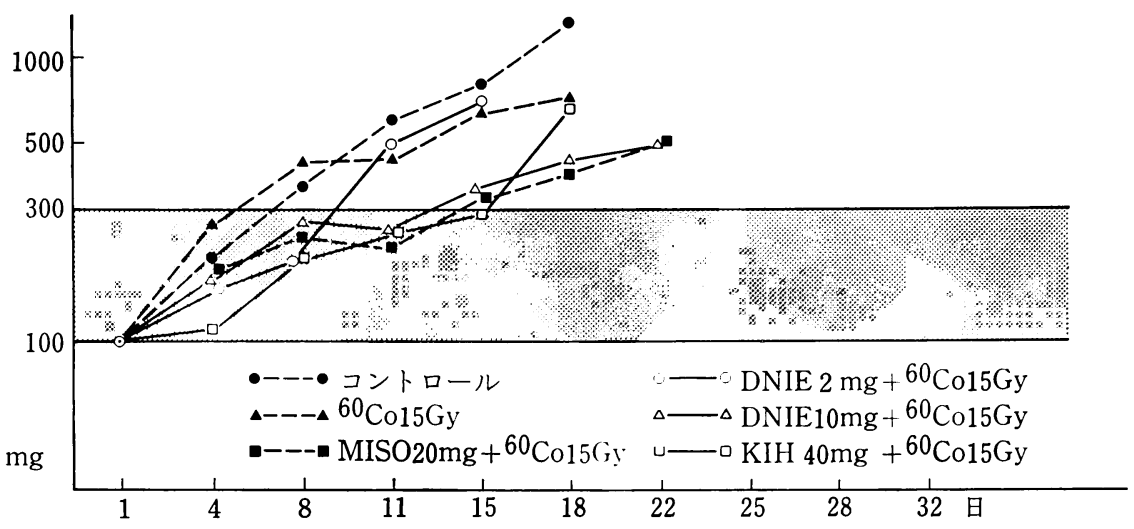

図 3 エールリッヒ癌の增殖曲線（ヌードこICR マウス）

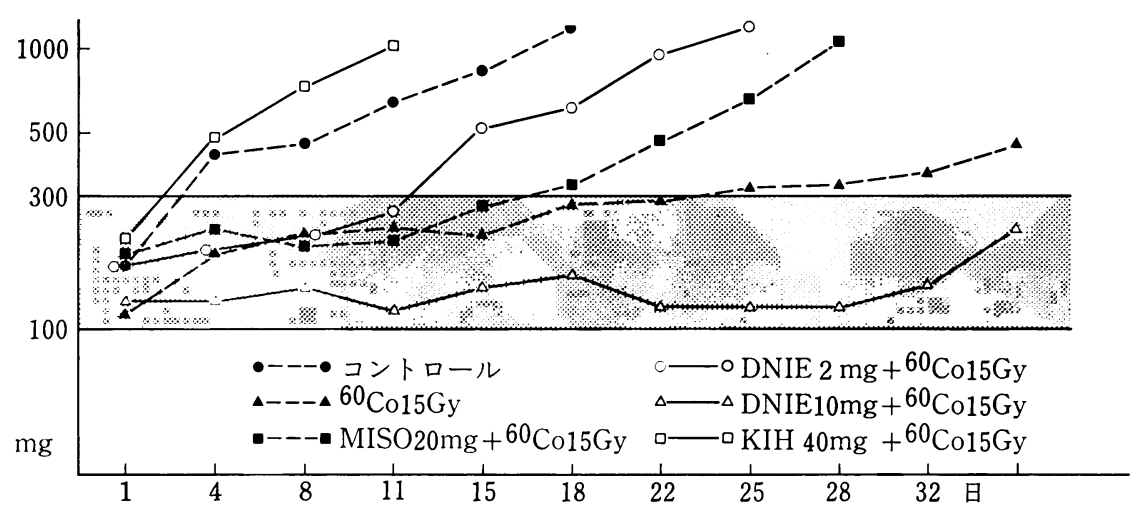

図 4 エールリッヒ癌の增殖曲線 ( $\mathrm{dd} \mathrm{Y}$ マウス)

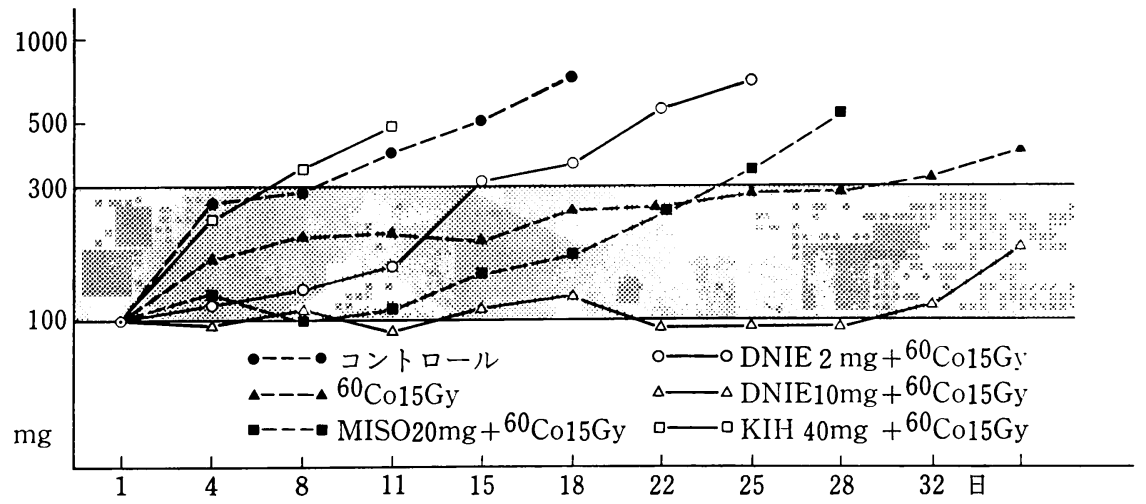

図 5 エールリッヒ癌の増殖曲線 (ddY マウス) 


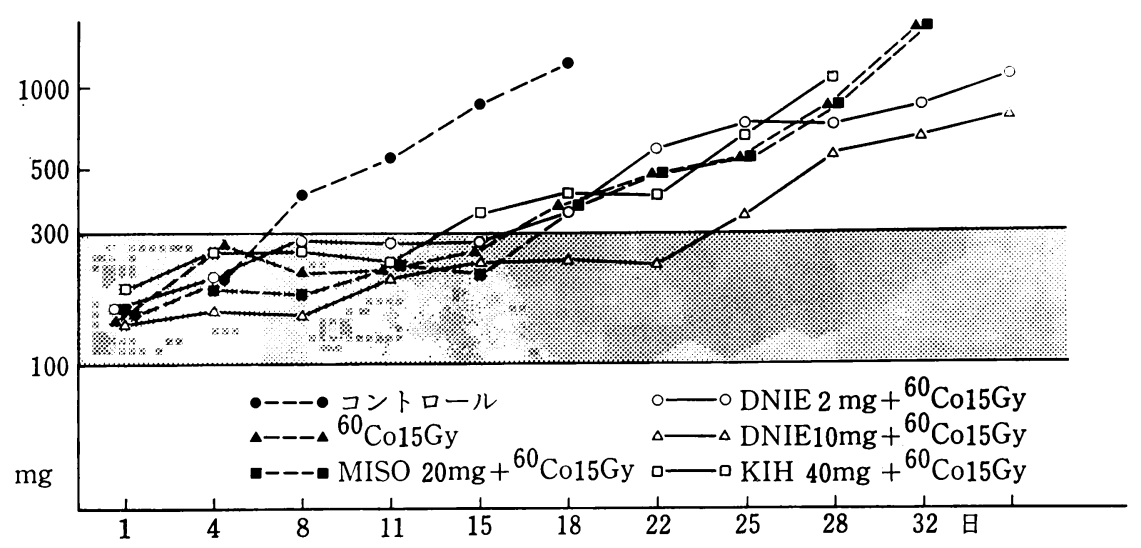

図 6 エールリンヒ癌の增殖曲線（通常 ICR マウス）

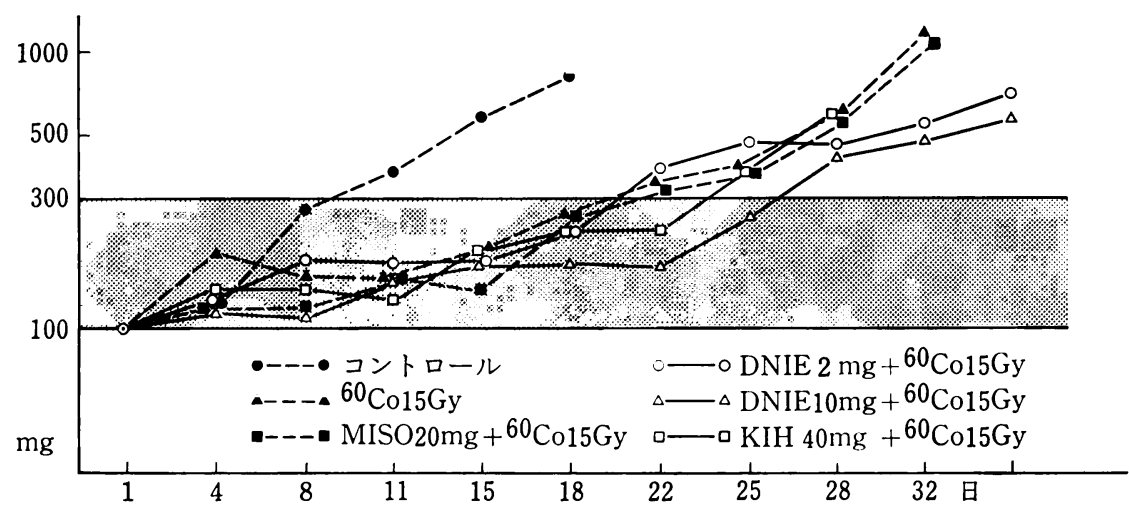

図 7 エールリッヒ㿔の增殖曲線（通常 ICR マウス）

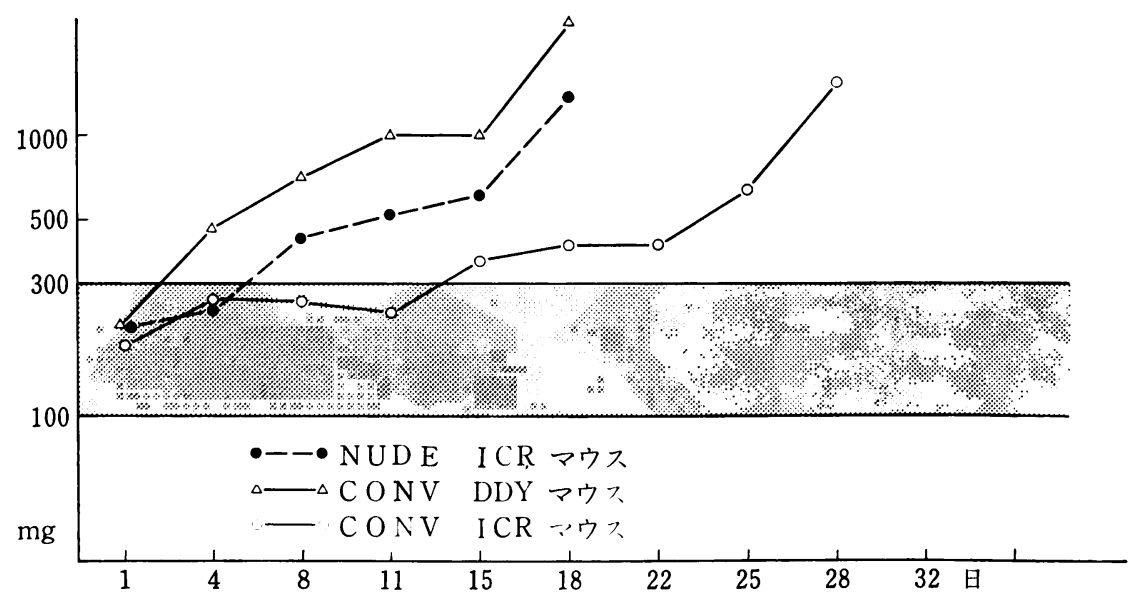

図 8 エールリッヒ㿔の增殖曲採 ( $\mathrm{KIH}-340 \mathrm{mg}+{ }^{60} \mathrm{Co} 15 \mathrm{~Gy}$ ) 
と，11日目頃より增殖に抑制が認められる DNIE $10 \mathrm{mg}$ $+{ }^{60} \mathrm{Co} 15 \mathrm{~Gy}$ 群 • MISO $20 \mathrm{mg}+{ }^{60} \mathrm{Co} 15 \mathrm{~Gy}$ 群・KIH $40 \mathrm{mg}+{ }^{60} \mathrm{Co} 15 \mathrm{~Gy}$ 群の 3 群とに二分化する傾向が認め られた。特に $\mathrm{KIH}$ 併用群についてみると，初期では增 殖抑制, 中期には他の 2 群と混交, 後期では増殖著明と なった。図 4 は ddY マウス上のエールリッヒ癌に対す る $\mathrm{KIH}-3 \quad 40 \mathrm{mg}+{ }^{60} \mathrm{Co} 15 \mathrm{~Gy}$ 併用治療群とその他の 治療群の腫瘍增殖を画いたグラフで，一見して治療法別 に散在しているのが特長である，実験開始時に最小であ った。 ${ }^{60} \mathrm{Co} 15 \mathrm{~Gy}$ 群は增殖抑制が良好で，スタート直 後に DNIE $10 \mathrm{mg}+{ }^{60} \mathrm{Co} 15 \mathrm{~Gy}$ 群を越えるが，長期間 横ばい状態が持続し，25日目に $300 \mathrm{mg}$ を超過した。下 位二位の DNIE $10 \mathrm{mg}+{ }^{60} \mathrm{Co} 15 \mathrm{~Gy}$ 群はスタート時の 重量がほとんど変化せずに経過し，18日目に軽度に上昇 したが再び下降して，35日目でも上昇傾向にはあるが $300 \mathrm{mg}$ にいたらなかった. $\mathrm{KIH} 40 \mathrm{mg}+{ }^{60} \mathrm{Co} 15 \mathrm{~Gy}$ を みるとスタート時の畽瘍は 6 群中最大で, ほとんと増殖 抑制効果は認められないようにみえる。 ${ }^{60} \mathrm{Co} 15 \mathrm{~Gy}$ 群 と MISO $20 \mathrm{mg}+{ }^{60} \mathrm{Co} 15 \mathrm{~Gy}$ 群はグラフが接近して両 者の抗腫湟効果が不明となるため, 図了の場合と同様に 補正グラフ図5を画いた。图 5 の KIH-3 併用群は 4 日 目ではコントロール群よりもやや増殖を抑制している が，8日目以後はコントロール群よりも増殖が進んでい る. 図6 は通常 ICR マウス上のエールリッヒ癌に対す る $\mathrm{KIH}-3 \quad 40 \mathrm{mg}+{ }^{60} \mathrm{Co} 15 \mathrm{~Gy}$ 群とその他の治療群の 腫瘍増殖を画いたグラフで，実験開始時では比較的腫瘍 の大きさに差がなかった，どの治療群も中等度の腫瘍增 殖抑制効果を示し，図７をみても明らかなよらにコント ロール群と他の治療群とは著明に相違していることが認 められた。図 8 は $\mathrm{KIH}-3 \quad 40 \mathrm{mg}+{ }^{60} \mathrm{Co} 15 \mathrm{~Gy}$ 併用治 療を行った 3 種類のマウス上のエールリッヒ癌の增殖曲 線で，どの群も腫瘍增殖抑制効果がほとんど認められな い.まずヌードマウスについてみると，実験開始より 8 日目にはすでに $300 \mathrm{mg}$ を超過, 18 日目では $1,000 \mathrm{mg}$ 以上に増殖, 図了を参照すればコントロール群に比較し 腫瘍増殖抑制効果が認められるが，絶対値的に観察する と抗腫瘍効果は弱いものと思われた。

$\mathrm{dd} Y$ マウスにおける腫湟はヌードマウスよりもさら に著明な増殖を示し，4 日目に $300 \mathrm{mg}$ を超過，11日目 には $1,000 \mathrm{mg}$ 以上となった.

图 5 を参照すればュントロール群よりも増殖が著明で あった，通常 ICR マウスにおける腫痬は 3 者の5ちで 最も抗腫湯効果の認められるもので，一度増殖しかけた 腫瘍が11日目では抑制されているのが分る，図 7 を参照 するとコントロール群よりも抑制が著明で, MISO 20 $\mathrm{mg}+{ }^{60} \mathrm{Co} 15 \mathrm{~Gy}$ 群とほぼ同様の抗腫瘍効果が認められ た. 表 1 は治療効果の判定を示したもので, 腫瘍増殖抑 制効果の認められたものは (十), 腫瘍の縮小を認めた ものは（H）で表した。 3 種類のマウスを通して（十）
表 1 結 果（コントロールとの比較）

\begin{tabular}{|c|c|c|}
\hline マウス & 治 療 法 & 判 定 \\
\hline Nude ICR & ${ }^{60} \mathrm{Co} 15 \mathrm{~Gy}$ & $(-)$ \\
\hline Nude ICR & MISO $20 \mathrm{mg}+{ }^{60} \mathrm{Co} 15 \mathrm{~Gy}$ & $(+)$ \\
\hline Nude ICR & DNIE $2 \mathrm{mg}+{ }^{60} \mathrm{Co} 15 \mathrm{~Gy}$ & $(-)$ \\
\hline Nude ICR & DNIE $10 \mathrm{mg}+{ }^{60} \mathrm{Co} 15 \mathrm{~Gy}$ & $(+)$ \\
\hline Nude ICR & $\mathrm{KIH} \quad 40 \mathrm{mg}+{ }^{60} \mathrm{Co} 15 \mathrm{~Gy}$ & $(+)$ \\
\hline $\operatorname{dd} \mathrm{Y}$ & ${ }^{60} \mathrm{Co} 15 \mathrm{~Gy}$ & $(+)$ \\
\hline $\operatorname{dd} Y$ & MISO $20 \mathrm{mg}+{ }^{60} \mathrm{Co} 15 \mathrm{~Gy}$ & $(+)$ \\
\hline $\operatorname{dd} Y$ & DNIE $2 \mathrm{mg}+{ }^{60} \mathrm{Co} 15 \mathrm{~Gy}$ & $(-)$ \\
\hline dd $Y$ & DNIE $10 \mathrm{mg}+{ }^{60} \mathrm{Co} 15 \mathrm{~Gy}$ & $(H)$ \\
\hline $\operatorname{dd} Y$ & $\mathrm{KIH} \quad 40 \mathrm{mg}+{ }^{60} \mathrm{Co} \quad 15 \mathrm{~Gy}$ & $(-)$ \\
\hline Conv. ICR & ${ }^{60} \mathrm{Co} 15 \mathrm{~Gy}$ & $(-)$ \\
\hline Conv. ICR & MISO $20 \mathrm{mg}+{ }^{60} \mathrm{Co} 15 \mathrm{~Gy}$ & $(+)$ \\
\hline Conv. ICR & DNIE $2 \mathrm{mg}+{ }^{60} \mathrm{Co} 15 \mathrm{~Gy}$ & $(-)$ \\
\hline Conv. ICR & DNIE $10 \mathrm{mg}+{ }^{60} \mathrm{Co} 15 \mathrm{~Gy}$ & $(+)$ \\
\hline Conv. ICR & $\mathrm{KIH} \quad 40 \mathrm{mg}+{ }^{60} \mathrm{Co} 15 \mathrm{~Gy}$ & $(+)$ \\
\hline
\end{tabular}

表 2 結 果 $\left({ }^{60} \mathrm{Co} 15 \mathrm{~Gy}\right.$ との比較)

\begin{tabular}{|c|c|c|}
\hline マウン & 治＜wide>療 & 判 定 \\
\hline Nude ICR & MISO $20 \mathrm{mg}+{ }^{60} \mathrm{Co} 15 \mathrm{~Gy}$ & $(-)$ \\
\hline Nude ICR & DNIE $2 \mathrm{mg}+{ }^{60} \mathrm{Co} 15 \mathrm{~Gy}$ & $(-)$ \\
\hline Nude ICR & DNIE $10 \mathrm{mg}+{ }^{60} \mathrm{Co} 15 \mathrm{~Gy}$ & $(-)$ \\
\hline Nude ICR & $\mathrm{KIH} \quad 40 \mathrm{mg}+{ }^{60} \mathrm{Co} \quad 15 \mathrm{~Gy}$ & $(-)$ \\
\hline dd $Y$ & MISO $20 \mathrm{mg}+{ }^{60} \mathrm{Co} 15 \mathrm{~Gy}$ & $(-)$ \\
\hline $\operatorname{dd} Y$ & DNIE $2 \mathrm{mg}+{ }^{60} \mathrm{Co} 15 \mathrm{~Gy}$ & $(-)$ \\
\hline $\operatorname{dd} \mathrm{Y}$ & DNIE $10 \mathrm{mg}+{ }^{60} \mathrm{Co} 15 \mathrm{~Gy}$ & $(+)$ \\
\hline $\operatorname{dd} Y$ & $\mathrm{KIH} \quad 40 \mathrm{mg}+{ }^{60} \mathrm{Co} \quad 15 \mathrm{~Gy}$ & $(-)$ \\
\hline Conv. ICR & MISO $20 \mathrm{mg}+{ }^{60} \mathrm{Co} 15 \mathrm{~Gy}$ & $(-)$ \\
\hline Conv. ICR & DNIE $2 \mathrm{mg}+{ }^{60} \mathrm{Co} \quad 15 \mathrm{~Gy}$ & $(-)$ \\
\hline Conv. ICR & DNIE $10 \mathrm{mg}+{ }^{60} \mathrm{Co} 15 \mathrm{~Gy}$ & $(+)$ \\
\hline Conv. ICR & $\mathrm{KIH} \quad 40 \mathrm{mg}+{ }^{60} \mathrm{Co} \quad 15 \mathrm{~Gy}$ & $(-)$ \\
\hline
\end{tabular}

以上の効果を示したものは, MISO $20 \mathrm{mg}+{ }^{60} \mathrm{Co} 15 \mathrm{~Gy}$ と DNIE $10 \mathrm{mg}+{ }^{60} \mathrm{Co} 15 \mathrm{~Gy}$ の 2 群であった. KIH 40 $\mathrm{mg}+{ }^{60} \mathrm{Co} 15 \mathrm{~Gy}$ が (十) を示したものは, ヌードマウ スと通常 ICR マウス上の腫瘍であった，表 2 は放射線 増感剤の増感効果を検索する目的で放射線単独照射と比 較した治療効果の判定で, 増感したと認められるものは 全12群のらち ddY マウスと通常 ICR マウスに拈ける DNIE $10 \mathrm{mg}+{ }^{60} \mathrm{Co} 15 \mathrm{~Gy}$ のみであった。

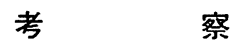

$\mathrm{KIH}$ 系は $\mathrm{NO}_{2}$ 基をもたないイミダゾール系増感阂 
で，KIH-1 から始まり，分子設計により多数の誘導体 が産生され，1985年 8 月現在 KIH-114 までが合成され ている4 このらちから，毒性が少なくヒトへの応用が 可能と考えられるものを選択, in vitro ではチャイニー ズハムスターV79細胞, in vivo では, ddY, 通常 ICR, ヌード ICR マウスに移植された癌について有効性が検 討されている。 KIH-3 は in vitro において MISO の $1 / 5$ の毒性といわれたが5,6)，in vivoに执いて MISO の 5 倍量を腹腔内投与 $(100 \mathrm{mg} /$ マウス) したが, 全例 (ヌ ード ICR マウス 5 匹・ddY マウス 5 匹・通常 ICR マ ウス 5 匹）が死亡した。これら 3 種類のマウスに対する 安全最大投与量を検討した結果 $40 \mathrm{mg} /$ マウゥスであった. この数值は $200 \mathrm{mg} / \mathrm{kg}$ とはなるが，われわれは現在ま で実験動物はマウスのみに試みただけであり, サル・ヒ トへの最適投与量は不明で, 本剤が非ニトロ系であると ころから，一トロ系の MISO の副作用と異なることも 十分考えられるため, perkilogram 表示をしないことと したい. KIH-3 $40 \mathrm{mg}$ 単独投与では抗腫瘍効果は認 められなかった。 KIH-3 の増感効果発揮機序は現在ま た十分に解明されていないが，マウス腹腔内注射後 30 分〜 2 時間までの腫瘲内濃度を高速液体クロマトグラフ ィーで测定したところ，KIH-3 の原型は認められなか った.

しかし図 7 でも観察される通り，抗腫瘍効果はMISO $20 \mathrm{mg}$ および DNIE $10 \mathrm{mg}$ 併用例とほぼ同様に認めら

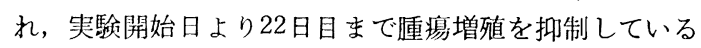
のは，第 2 報の DNIE と同様恐らく代謝産物が体内に 残留して, 增感効果をあげているものと推定される。

マウス別に KIH-3 併用の治療効果をみると、 ヌード マウス群および通常 ICR マウス群ではコントロール群 よりも抗腫瘍効果を認めているが, dd Y マウス上の腫 厡は抑制を示ず, コントロール群の增殖曲線以上の発育 が認められ、この增殖バターンを検索したところヌード マウス・コントロール群のグラフとほとんど同一の曲線 であった，KIH-3 併用治療の各マウスの実験開始時腫 瘳重量はヌードマウスが $203.0 \mathrm{mg}, \mathrm{dd} Y$ マウスが 211.0 $\mathrm{mg}$, 通常 ICR マウスが $186.7 \mathrm{mg}$ とほぼ同様の重量で, 特に dd $\mathrm{Y}$ マウスのものが進行例ではなかったが, 增感 剂併用であるのにコントロール群を上回る增殖を認め た。この理由として稂ら゙が報告したように，効果は癌 細胞の差よりもマウスの系統による差異が著明であるこ と，さらに野本ら ${ }^{8)}$ の説えるその実験系によく適合する 実験動物の選択も必要となる。たとえば今回の实験では 著明な增殖を示したが，DNIEを中心とした垁験中， $\mathrm{ddY}$ 系上の腫場は 5 匹 1 群で平均重量 $142.5 \mathrm{mg}$ で轪験 を開始， 4 日目 $105.6 \mathrm{mg} ， 8$ 日目 $81.7 \mathrm{mg}, 11$ 日目 53.2 $\mathrm{mg}, 15$ 日目 $43.4 \mathrm{mg}, 18$ 日目 $30.9 \mathrm{mg}, 22$ 日目 $21.6 \mathrm{mg}$, 25 日目 $7.1 \mathrm{mg}$, 29日目 $0 \mathrm{mg}$ と順次減少 ${ }^{97}$, 29 日目には 5 匹すべての腫瘳が肉眼的に消失しその後 6 か月間钼察を
続けたが再発を認めず，実験を終了した。その後追試を 繰り返したが腫瘍消失したものはなく，実験の平均値を 第 2 報に報告した。これらの現象を解明するには，マウ スおのおののリンパ球活性を明らかにすることが必要 で, この方面の今後の研究が期待される. dd Y マウス 上腫湯の異常な增殖のも5 1 つの理由として, KIH-3 の与える副作用が問題となる。すなわち $\mathrm{KIH}-3$ は ddY マウスの抗腫瘍機構を著しく障害したか，あるいは ddY マウスにおいては増感効果が現れにくいなどである。

前述した母里りによればヒトにおいてもどんな免疫背 景をもつ宿主に，どんな腫瘍が存在しているかが治療の 際に大きな問題となる。 また，MISO の臨床効果が悪い のは, 再発例・進行例に使用したためではなかったかと 述べ, Panduro $5^{(0)}$ は手術不可能な肺癌に MISO 併用 を試みたが，プラセボー併用よりも効果が悪く、これも 手術不能進行例の成績であるため効果が低いのではない

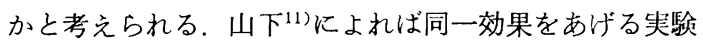
治療線量は in vivo < in vitro で in vivo が少なくてすむ のは生体のもつ免度反応が作用するからであると述べて いる.ささに山下ら ${ }^{12}$ は全身照射は免度が低下するが, 局所照射は免疫を上昇させると述べている。.土屋 ${ }^{13,14)}$ 同様に局所照射の場合，その部分の組織細胞の放射線 死の面だけでなく，免疫の関与を考える必要があり， $\mathrm{C} 3 \mathrm{H} / \mathrm{He}$ マウスの両側脚に MM 46 尰序を移植, 片方 に $20 \mathrm{~Gy}$ 局所照射すると他方の腫沮も消失したと報告 している. この現象は abscopal effect と呼ばれ, Fletcher ${ }^{15)}$, Murphy ${ }^{16)}$, 戸部 ${ }^{17)}$, Nobler ${ }^{18)}$, 後藤田 ${ }^{19)}$, 松 原ら ${ }^{20)}$ によって報告されている。 また凍結外科分野にお いても abscopal effect が認められることが報告されて いる.これらの反応を推定すれば, 刺激された腫堭部位 から腫瘍抗原性が放出し, 自己の免疫作用が活性化して 新たな全身的抗嗹㾔システムができ上り, 他部位の腫痺 にまで影響を及汇し，樎小もしくは消失させると思わ れ，リンパ球が大きく関連しているであろらと考えられ ている，放射線增感凨の投与方法はマウスにおいては腹 腔内投与が多く行われているが，ヒトに扎いては静注・ 動注が一般的で MISO は経口投与が可能であった。 Sealy ら $^{21}$ は最近粉状 MISO を穿刺器を介して腫瘍内 に刺入し，頭頸部悪性腫惶の治療を行っている，MISO の作用は総じて浱度低存性といわれるところから, 新增 感剤も十分これらの問題を検討し, マウスに护ける投与 方法においても，刺入法も試行されるべきと考えてい る.

\section{結語}

3 種類のマウスにエールリッヒ固型癌を移植し，イミ ダゾール化合物のうちニトロ基をもたないKIH-3 の增 感作用を検討した。 
1）体重 20〜25 g のマウスに対し，KIH-3は $40 \mathrm{mg}$ 使用可能であった.

2) ヌードマウス上のエールリッヒ癌に対する $\mathrm{KIH}-3$ $40 \mathrm{mg}+{ }^{60} \mathrm{Co} 15 \mathrm{~Gy}$ 例はコントロール例に比较し, わず かながら腫瘍抑制効果が勝っていた。

3) ヌードマウス上のエールリッヒ癌に対する KIH-3 $40 \mathrm{mg}+{ }^{60} \mathrm{Co} 15 \mathrm{~Gy}$ 例は ${ }^{60} \mathrm{Co} 15 \mathrm{~Gy}$ 単独照射例に比較 し，特に增感効果は認められなかった。

4) ddY マウス上のエールリッヒ癌に対する $\mathrm{KIH}-3$ $40 \mathrm{mg}+{ }^{60} \mathrm{Co} 15 \mathrm{~Gy}$ 例は腫瘍を増覀させ，コントロール 例よりも著しい增殖を認めた。

5 ）通常 ICR マウス上のエールリッヒ癌に対する KIH-3 $40 \mathrm{mg}+{ }^{60} \mathrm{Co} 15 \mathrm{~Gy}$ 例はコントロールに比校し て，かなり良好な抗腫掦効果が認められた。 ${ }^{60} \mathrm{Co} 15 \mathrm{~Gy}$ 単独照射と比較すると効果に差はなく，両者はほとんど 同様であった。

6) 同一腫瘍に対しても, 宿主の相違による効果の差 が認められた。

7）イミダゾール化合物のらち，二トロ基を有するる のの方が増感作用が勝れていた。

稿を終えるに臨み，KIH-3 の分与をいただいた度応 義塾大学医学部薬化学研究所稲山誠一教授, ${ }^{60} \mathrm{Co}$ 照射に こ協力いただいた本学放射線科学教室 II 丹里知之教授・ 放射線技士各位扣上び本学共同利用研究施設橋本一男教 授・動物舎田中睦男氏・兼井浩氏に感謝の意を表しま す.

な扰，本論文の一部は日本薬学会第 104 年会, 昭和59 年厚生省がん研究がん放射線療法に打计万化学增感の研 究田中班班会議において発表した。

\section{引用文 献}

1）酒泉和夫, 瀬沼 滋, 他：マウス移植悪性腫源 に対するイミダソール化合物の放射線增感作用 について—第1 報: エールリッ七固型癌に対 するミソニダソールの放射線增感作用—— 日 口外誌 31: 1827-1833 1985.

2）酒泉和夫，瀬沼 谈，他：マウス移植悪性腫崲 に対するイミダンール化合物の放射線增感作用 について—第 2 報：エールリッ七固型癌に対 する dinitroimidazole ethanol の放射線增感作 用一一。口外誌 32: 8-14 1986.

3）酒泉和夫, 瀬沼 滋, 他：七上上顎扁平上皮癌 移植又ードマウスに扮ける放射楾增感剂 misonidazole の効果. 日外誌 28: 1662-1666 1982.

4）稲山諴一, 酒泉和夫, 他：非二卜口系增感剂の in vitro 効果と非二トロ系 DNIE の in vivo 効 果。厚生省がん研究, がん放射線療法に打ける 化学增感の研究, 田中班。昭和60年度（8月） 第 1 回班会議。

5) 丹:里知之: 低酸素細胞增感郕( その 1 )。臨床放 射線 28: 727-728 1983.

6) 母: 里知之, 芝田千患子, 他: Hypoxic cell sensitizer in vitro. 癌の臨床 27：1447-1451 1981.

7）檘 武彦, 吉田菊喜: がんの実験モデル。臨床 免疫 17：149-159 1985.

8）野本亀久雄, 谷口 微, 他: 免疫応答促伝子支 配々修飾因子。臨床免疫 7：971-979 1975.

9）酒泉和夫, 佐藤一人, 他：イミダゾール謤尊体

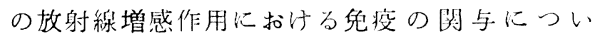
て。日本莯学会第104年会 昭和59年 3 月。

10) Panduro, J., Kjaer, M., et al. Misonidazole combined with radiotherapy in the treatment of inoperable squamous cell carcinoma of lung:A double blind randomized trial. Cancer 52: 20-24 1983.

11）山下 孝：マウスに扣ける細胞性腫瘍免疫能に 対与る放射線の効果。日医放会誌 41：887-893 1981.

12）山下 孝, 早川幸子, 他: 腫瘍一の放射線照射

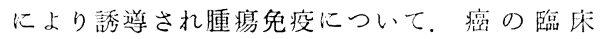
29: 1506-1511 1983.

13）土屋武彦：局所照射に打斿色疫作用の役割, 1 抗腫㻛科胞性免疫について。日医放会誌 36 : 922-929 1976.

14）土屋武彦：放射線治療に打的急疫機能の阅 与。癌の臨床 29: 1499-1505 1983.

15) Fletcher, G.H.: Text-Book of Radiotherapy. Lea \& Febiger, Philadelphia, 1966, p 80.

16) Muphy, W.T.: Radiation Therapy. 2 nd Ed, Saunders Co, Philadelphia, 1967, p 944.

17) 戸部竜夫：放射線治療の生物学的考察。日医放 会誌 28：690-713 1968.

18) Nobler, M.P.: The abscopal effect in malgnant lymphoma and its relationship to lymphocyte circulation. Radiology 93: 410-412 1969.

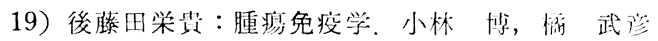
編集, 朝信書店, 東京, 1974, 427-430面。

20）松原 升, 堀内涼一. Abscopal effect の奴られ た皮首細網肉腫症の一例。日医放会誌 35：8608671975.

21) Sealy, R., Korrubel, J., et al.: Intersitial misonidazole. A preliminary report on new perspective in clinical radiation sensitization and hypoxic cell chemotherapy. Cancer 54 : 1535-1540 1984. 